\title{
MEMÓRIA INFANTIL, ESCOLAR E LITERÁRIA EM POESIAS INFANTIS, DE OLAVO BILAC
}

\author{
Ana Paula Serafim Marques da Silva \\ Mestre em Letras pela UFPB \\ anapaulasms0108@gmail.com. \\ Daniela Maria Segabinazi \\ Professora Doutora do Programa de Pós-Graduação em Letras da UFPB \\ dani.segabinazi@gmail.com.
}

\section{RESUMO}

Neste artigo, abordamos questões sobre a memória da infância, da literatura e da escola republicana presente na obra Poesias infantis (1904), do escritor fluminense Olavo Bilac. Consagrando o discurso poético infantil brasileiro, a coletânea, que foi escrita, arquitetada e publicada para fins escolares, abarca os valores socioculturais e pedagógicos propagados durante a implantação do regime republicano brasileiro, os contornos da nossa educação e as marcas do início da literatura infantil escolar. Esta pesquisa de caráter bibliográfico e interpretativo, buscou examinar as seções poéticas das estações e dos meses e a sua articulação com o espaço escolar, tanto físico como figurado, as noções de temporalidade, o diálogo com outras artes e a interdisciplinaridade. Com o intuito de entender a educação estética e as práticas escolares e literárias que deram sentido à escritura em estudo, valemo-nos das considerações de Escolano (2001), Faria Filho \& Vago (2001), Lajolo (1982) e Veiga (2011).

Palavras-chave: Olavo Bilac, Literatura Infantil Brasileira, Poesia Infantil, Memória escolar.

\section{RESUMEN}

En este artículo, abordamos cuestiones sobre la memoria de la infancia, de la literatura y de la escuela republicana presente en la obra Poesias infantis (1904), del escritor fluminense Olavo Bilac. Con la consagración del discurso poético brasileño, la colección, que fue escrita, estructurada y publicada para fines escolares, abarca los valores socioculturales y pedagógicos propagados durante la implantación del régimen republicano brasileño, los lineamientos de nuestra educación y las marcas del comienzo de la literatura infantil escolar Esta investigación de carácter bibliográfico e interpretativo, que buscó examinar las secciones poéticas de las estaciones y de los meses y su articulación con el espacio escolar, tanto físico como figurado, las nociones de temporalidad, el diálogo con otras artes y la interdisciplinariedad. Con el fin de entender la educación estética y las prácticas escolares y literarias que dieron lugar a la escritura en estudio, nos valemos de las consideraciones de Escolano (2001), Faria Filho \& Vago (2001), Lajolo (1982) y Veiga (2011).

Palabras clave: Olavo Bilac, Literatura Infantil Brasileña, Poesía Infantil, Memoria escolar. 


\section{INTRODUÇÃO}

Os livros de leitura que circularam durante o século XIX e parte do século XX são exemplos de produtos culturais do período de produção, recepção, utilização e circulação do qual fazem parte, pois apresentam tendências, gostos, necessidades e transformações que perpassam o campo educacional e literário do período. São obras que fazem parte da cultura escolar na transição Império-República e, portanto, a partir dessa produção, podemos compreender "[...] a imagem de criança que a literatura infantil brasileira assumiu e pôs em circulação ao longo de sua constituição enquanto modalidade cultural." (LAJOLO, 1993, p. 23).

Nesse panorama, empreendemos um esforço investigativo em Poesias infantis (1904), obra poética do escritor fluminense Olavo Bilac (1865-1918). Um livro de leitura resultante de uma encomenda da editora Francisco Alves, gestada em 1896, e organizada para "[...] uso das aulas de instrucção primaria [...]" (BILAC, 1916, p. 1). Abarcava, na época, os cinco primeiros anos de escolarização, permanecendo até 1961 como uma das mais importantes obras de dimensão poética brasileira que se tinha disponível nas escolas para a infância no século XX (ZILBERMAN, 2014). O impresso se constitui um arquivo histórico representativo e bem-sucedido da escola republicana, consagra o nosso discurso poético infantil tradicional e revela uma memória da infância do final do século XIX e início do XX.

Ao estudar a obra, compreendemos os valores socioculturais da época, os contornos da nossa educação, a valorização da memória nacional, além de percebermos as marcas do início da literatura infantil escolar, constituindo um modelo ilustre da criação literária infantil inserida no sistema cultural daquele tempo. Por conseguinte, nosso intuito principal é afirmar o quanto a obra contribuiu para a formação intelectual, estética e cultural do público 
infantil e juvenil entressecular. Assim, analisamos, por determinados ângulos, a memória escolar por intermédio do espaço, do tempo e das práticas escolares que a organização didática das seções do compêndio revela.

Deste modo, além desta introdução e da conclusão, o trabalho divide-se, em duas partes. Escolhemos perquirir, no primeiro tópico, tanto os poemas que compõem a seção referente às estações, quanto à articulação deles com outras artes, como a dança, a música e o teatro, assim como, as práticas comunitárias de realização de celebrações agrícolas. Já no tópico seguinte, abarcamos a seção dos meses, enfatizando que os poemas trazem o tempo como um organizador social e escolar, bem como, as datas comemorativas impostas pelo regime republicano.

Vale ressaltar que os poemas manifestam em sua composição escrita, acompanhadas de ilustrações, os aspectos escolares que são formados por "[...] seu tempo, espaços, sujeitos e modos de organização e transmissão de conhecimentos [...]" (FARIA FILHO; VAGO, 2001, p. 120), evidenciando práticas e representações do seu tempo, corroborando os objetivos e os sentidos para o material em análise. Para Roger Chartier (2002, p. 127), reconstruir o sentido de uma obra exige considerar três relações estabelecidas entre os seguintes polos: "[...] o texto, o objeto que the serve de suporte e a prática que dele se apodera." Desse modo, a pesquisa tem natureza bibliográfica com dimensão interpretativa, buscando expor poemas das seções que revelam a memória e o espaço escolar, o sistema político e as práticas da sociedade entressecular.

Tomamos como fonte de análise a edição de 1916 da obra. A preferência por esse exemplar se dá pela aproximação com o contexto de sua circulação no Brasil, algo que as reedições mais atuais acabaram perdendo ao alterarem o projeto gráfico, apesar de o 
suporte permanecer o mesmo. Ressaltamos que foi mantida a ortografia da época nas citações dos versos, acompanhando a edição em análise.

\section{A SEÇÃO DAS ESTACÕES: A REPRESENTAÇÃO DAS PRÁTICAS ESCOLARES}

Poesias infantis é composta por cinquenta poemas e quatro fábulas, abarcando diversos temas, dentre eles: a natureza, a virtude, a memória, o tempo, o trabalho etc. Marisa Lajolo (1982) comenta sobre a disposição dos poemas no livro, apontando que o autor tende a agrupá-los pelos que possuem traços em comum, como os poemas que tratam das fases da vida humana, dos elementos da natureza, dos assuntos religiosos, do elemento virtuoso, das horas diárias e do calendário anual. Ademais, o exemplar foi esquematizado por temas ostensivos ligados a uma sociedade rural e arcaica e se relacionam com os valores ideológicos que caberia à escola defender (LAJOLO, 1982).

Vale ressaltar que o público escolar do entresséculos era quase sempre composto por filhos de fazendeiros, o que reforça a presença desses valores, concedidos por meio da natureza, no ambiente escolar. Conforme Nelly Novaes Coelho (2006, p. 20) era frequente nos livros de leitura de então a "[...] ênfase na vida rural e, consequentemente, idealização da vida no campo, em oposição à vida urbana." Diante disso, concordando com Luciano Mendes de Faria Filho e Tarcísio Mauro Vago (2001), a escola se adaptava à vida das pessoas, visto que considerava os costumes locais nos quais o sujeito estava inserido. Assim, justificamos nossa escolha em abordar as composições das seções "As Estações" e "Os Mezes" - quando pertinente, mencionamos outras composições poéticas -, apresentando as práticas que a sociedade vivenciava, as quais a coletânea levou para o espaço escolar. 
Percebe-se, nos poemas da seção em questão, o forte louvor à natureza, especificamente uma contemplação às estações do ano. Segundo Lajolo e Zilberman (2010), a natureza é um dos símbolos mais difundidos da nacionalidade desde o período colonial. No entanto, na transição entre o Império e a República, firma-se, no Brasil, uma consciência de exaltação ao ambiente natural e de todos os elementos da fauna e da flora pertencentes a ele. Como aponta Lajolo (1982), há um espaço destinado à natureza nas produções poéticas de Bilac, seja nas endereçadas aos leitores da imprensa carioca, seja naquelas destinadas ao consumo infantil.

Nesse viés, Poesias infantis (1904) representa uma total comunhão com a natureza, por meios das ilustrações, que na sua maioria se remetem ao ambiente de campo, ou pelos versos. Por intermédio de um mapeamento, podemos citar os poemas que apresentam bichos como elementos da natureza: "O Passaro captivo", "A Borboleta", "As formigas", "Plutão", "O Boi"; e as que contemplam os outros elementos da natureza, como, por exemplo: "O Sol”, “As Estrellas", “A Vida”, "A Madrugada”, "As flores", "O Rio", "As velha Arvores" e "A Patria". Há também a presença das fábulas com autoria atribuída a Esopo (escravo grego que viveu no século VI a.C.) - "A Rã e o Touro", "O Leão e o Camondongo" e “O Lobo e o Cão". Além disso, "As Formigas", disposta no compêndio logo após a seção das estações, remete à clássica fábula da cigarra e da formiga, também de Esopo.

Pensando na valorização de elementos ligados ao ruralismo, Olavo Bilac dedica uma seção à exaltação das estações do ano, intitulada: "As estações canto e dansa". Trata-se de um conjunto de poemas que contempla o caráter exuberante e encantatório das quatro estações do ano, as quais são devidamente representadas por poemas intitulados: "O inverno", "A primavera", "O verão" e "O outono". Todos são ilustrados, representando, 
possivelmente, o ambiente rural onde as famílias aproveitavam o que cada época pode oferecer: chuva, flores, sol e frutos. Como coloca Lajolo (1982, p. 129), a referida parte se difere das demais composições do exemplar por se constituírem como "[...] rituais de celebração agrícola que Bilac desloca para a instituição escolar.", uma exortação à natureza que não afeta o universo do dever, pois se dirige ao "[...] respeito à liturgia das ações comunitárias, ao lazer.".

Estruturalmente, os poemas da seção em análise dividem-se em duas partes: a do coro, intitulado "Côro das quatro estações", localizado no início e no final dos poemas, constituído por uma quadra com rimas cruzadas externas seguindo o esquema $A B A B$; e por três estrofes sextetas com rimas misturadas (emparelhadas e interpoladas), obedecendo ao esquema $A A B C C B$, ambas as partes escritas em versos heptassílabos.

Percebe-se, já a partir do título da seção e da ilustração (cf. Figura 1), o tom festivo dos poemas que virão e a forte referência ao canto e à dança, consideradas por Alves (2016) ações que estão presentes na sociedade desde os tempos primitivos. Dessa maneira, o poema se funde conceitualmente ao canto desde muitos séculos em nossa cultura literária, como, por exemplo, nas cantigas de amor e de amigo na era medieval (MARICONI, 2002). 
Figura 1- Reprodução fotográfica da ilustração da seção "AS ESTAÇÕES CANTO E DANSA".

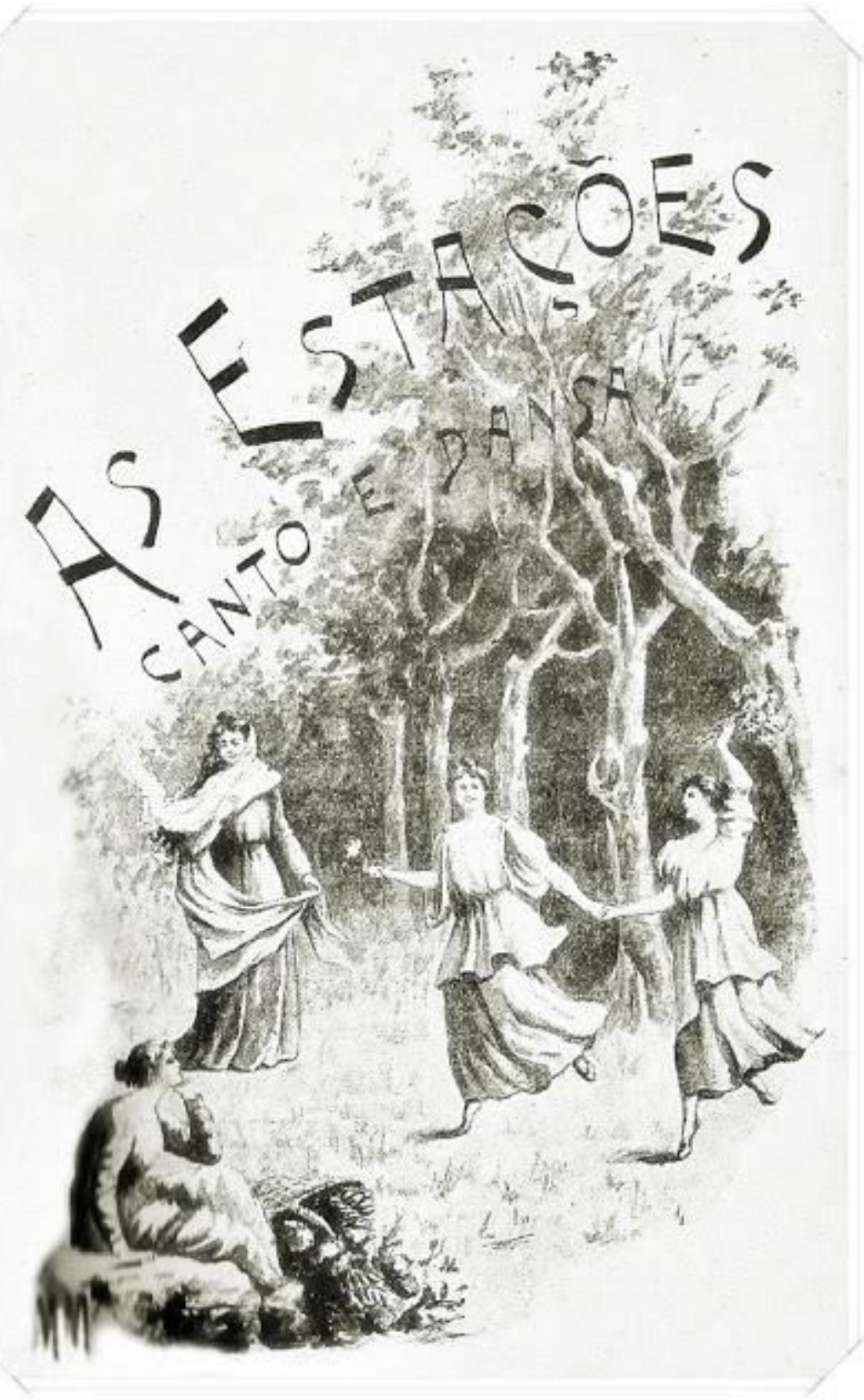

Fonte: Acervo particular. 
A imagem de abertura da seção tematiza uma cena de dança por intermédio de três das quatro mulheres, vestidas à moda romana (lembrando a figura de Atenas), apresentando alegremente gestos dançantes em local aberto evocando a natureza.

O coro, formado por versos de sete sílabas, também cumpre a função de um refrão, já que se caracteriza como um grupo de versos que se repete ao longo dos poemas e "[...] facilita a memorização nas canções, tendo um papel rítmico importante em todas as épocas." (GOLDSTEIN, 1989, p. 41). Desta forma, o coro sugere um ritmo, uma melodia e uma sonoridade bastante agradável, ao gosto do leitor mirim. Observemos tal questão no coro do poema de abertura da seção, "O inverno": "Cantemos, irmãs, dansemos!/ Espantemos a tristeza!/ E dansando, celebremos/ A gloria da Natureza!" (BILAC, 1916, p. 31). Assim, nota-se a forte articulação da dança e da canção às composições em estudo. Ademais, a presença de tais elementos musicais pode sinalizar, também, certa postura dos professores do entresséculos, pois, conforme Cynthia Greive Veiga (2011, p. 412), eles “[...] deveriam ter gosto artístico, sentimento e a inteligência do canto [...]".

Ainda, em "O inverno", há um ritual de passagem dessa estação, que seria a menos alegre por ser chuvosa, para a feliz chegada da primavera. Vejamos a penúltima estrofe do poema: “Porém fóra a tristeza!/ Em breve, a Natureza/ Dá Flores ao jardim:/ Abramos a janella!/ Outra estação mais bela/ Já vem depois de mim." (BILAC, 1916, p. 32). Dos quatro poemas que compõem a seção, o exposto acima se diferencia dos demais por antecipar a chegada da próxima estação, o que transfere ao poema um caráter narrativo. De certa forma, o andamento da composição poética nos apresenta o que virá, ou seja, indicando uma sucessão temporal e os passos a serem seguidos para a sua possível encenação. 
Assim, além da ligação com a música, impende destacar ainda que as referidas composições poéticas contêm uma orientação para sua devida encenação representada tanto pelo conteúdo quanto pela sua própria divisão interna. Desse modo, a presença de um coro nos poemas implica uma existência de uma parte solo, sinalizando mais uma função para Poesias infantis (1904): proporcionar ao leitor o contato, para além do canto e da dança, com o teatro. Possivelmente, a presença de um coro nos poemas da seção em questão indica que eles eram utilizados para encenação teatral escolar. Conforme Veiga (2011), essa prática era recorrente nas escolas republicanas e fazia parte de uma educação estética que incluía festas e espetáculos escolares, em que:

[...] o despertar para a civilidade não se faria apenas com a abertura de escolas, mas com uma educação estética que envolvesse habilidades manuais, a educação das mulheres para o lar, o contato com a literatura brasileira, os cantos, a dança, presentes no cotidiano das salas de aula, nas festas escolares, nas festas das cidades [...] (VEIGA, 2011, p. 407).

Ainda, em consonância à autora, a educação estética cumpria o papel de civilizar as classes inferiores e estaria sempre associada ao conceito de civilidade e de virtude. A introdução das atividades de canto, de dança, de teatro e da literatura no currículo escolar visava, sobretudo, ao aperfeiçoamento dos sentidos - olhar, ouvir, recitar etc., como parte do desenvolvimento intelectual do sujeito (VEIGA, 2011). Ademais, as emoções proporcionadas por esse modelo de educação despertavam o prazer, retirando as atividades de seu estado meramente utilitarista. Dessa forma, pela fácil musicalização, as crianças poderiam cantar o poema enquanto fariam a encenação, constituindo, assim, uma excelente estratégia para estimular a expressão oral. 
Nesse prisma, sempre seguindo um modelo europeu de educação, Poesias infantis (1904) - observado tanto na estética da materialidade do impresso, já que o mesmo foi editado em Paris, quanto nos temas e nas imagens que os poemas difundem, tendo em vista que o período inicial da República caracterizou-se por circulação de ideias advindas da Europa - representa a memória das práticas escolares que integrava diversas artes, como também a proteção aos animais, às árvores, aos rios etc.

Consoante a isso, Agustín Escolano (2001, p. 42), sugere que as máximas em favor dos animais e das árvores foram também inscritas frequentemente nas escolas europeias, pois “[...] as propostas de exaltação naturalista e romântica feitas pelos regeneracionistas, os quais acreditavam no poder civilizatório da terra e do bosque [...]", por isso, como se pode perceber, a partir de um tom de defesa ecológica discursivamente posto, essa forte presença da natureza pôde contribuir junto à formação das crianças da época, seja ajudando a compreender as variações climáticas ao longo do ano, ou mesmo na organização do tempo e do calendário escolar - os quais iremos nos ater no tópico a seguir -, pois a obra está encarnada às condições que permeiam sua produção.

\section{A SEÇÃO DOS MESES: O TEMPO COMO UM ORGANIZADOR SOCIAL E ESCOLAR}

No regime que se consolidava, a expansão escolar englobava ações que se voltavam para a organização do ensino, a fim de estabelecer uma sistematização dos saberes na escola e propagar conhecimentos voltados à redefinição do tempo e do espaço escolar (VEIGA, 2011). Nesse viés, analisaremos a seção poética intitulada "Os mezes canto e dansa" que, além de trabalhar a questão do tempo atrelado ao calendário escolar, também tem

uma forte colaboração na formação cultural e na identidade nacional. Assim, uma das 
funções a que esse material de renovação cultural deveria atender seria a realização de comemorações cívicas, para organizar as datas comemorativas impostas pelo estabelecimento do novo regime e que a escola tornava obrigatória (LAJOLO, 1982).

O segmento poético divide-se em doze composições ilustradas que seguem o esquema da outra seção: constituídas pela parte do coro - duas quadras escritas em versos octossílabos, seguindo o esquema $A B A B$ de rimas externas - e pela parte do solo representada pelos poemas "JANEIRO”, "MARÇO”, “ABRIL”, “JULHO” e "SETEMBRO” que são formados por versos hexassílabos. Os demais poemas que completam o conjunto dos meses do ano são constituídos por redondilha maior. No entanto, todos do bloco são divididos em três sextilhas, possuindo rimas misturadas (emparelhadas e interpoladas), obedecendo ao esquema $A A B C C B$. Esta seção é carregada de um contágio cênico mais acentuado que a anterior, o coro que inicia cada poema basicamente é composto pelos versos: "Venham os mezes desfilando!/ Cante cada um por sua vez!/ Dansemos todos, escutando/ O que nos conta cada mez..." (BILAC, 1916, p. 75). Há variação de palavras apenas nos dois primeiros versos do coro em alguns poemas, nada significativo que chegue a alterar o seu sentido.

Quanto ao coro de encerramento de cada texto versificado, diferente da seção que analisamos anteriormente, não há uma retomada do coro inicial, mas sim uma nova quadra que faz menção ao mês que virá, dando um caráter narrativo à seção. À medida que avançamos a leitura dos poemas, percebemos a clara abordagem dançante e dramática, principalmente, pela descrição dos coros, que verbaliza a movimentação dos participantes, ao fazer menção à roda, ao ensaio, ao rodopio, o que confere à presente seção uma marcação lúdica e teatral bem mais precisa (LAJOLO, 1982). Destacamos o coro de encerramento do poema "ABRIL": "Um novo passo agora ensiao [sic]:/ Dansemos todos 
outra vez!/ Entre na roda o mez de Maio,/ Sáia da roda o quarto mez" (BILAC, 1916, p. 82, grifo nosso). Conforme Raquel Zumbano Altman (2013), nessa época, a roda é um importante instrumento que une o espírito associativo e a educação musical. Ainda se observa nos versos mais uma função para o coro: a contagem matemática de cada mês, visto que a voz poética vai ditando pela representação dos números o mês que virá, assim, como uma forma de relembrar a criança sobre a constituição do tempo.

Andréa Bezerra Cordeiro (2005, p. 78), em sua dissertação, afirma haver cerca de vinte poemas na obra que abarcam o viés do tempo pelas seguintes perspectivas: “[...] exaltam a exemplar harmonia do tempo nos fenômenos da natureza.", outros que, por intermédio de animais, revelam, "[...] o exemplo de aproveitamento do tempo com disciplina e assiduidade.", alguns mais que "[...] se referem ao bom uso do tempo nos ciclos da vida humana.", ao "[...] uso racional do tempo de descanso." e à "[...] exaltação e [...] vinculação do tempo útil à prosperidade." (CORDEIRO, 2005, p. 79). A estudiosa ainda expõe que tal tema, na obra, é exposto com o propósito de alertar as crianças quanto às suas responsabilidades em fazer bom aproveitamento do tempo.

Já Lajolo (1982, p. 135) interpreta o tempo como signo do dinamismo, em que seus predicados são sempre "[...] paradigma de realização, de ação desenfreada, de dinamismo ininterrupto.". Concordando com as autoras, entendemos que o poeta concebe a vivência do tempo, pela criança, por vários sentidos. Para tanto, atrelado ao viés apontado pelas estudiosas, trazemos tal temática com intuito de elencar os aspectos do tempo como um organizador social e escolar, vinculados aos anseios de então, pois os tempos escolares não podem "[...] ser desligados das relações e dos tempos sociais dos quais a escola participa ativamente [...]" (FARIA FILHO; VAGO, 2001, p. 118). 
Nesse ponto, juntamente com os já citados poemas da seção das estações, outras composições poéticas do livro serviriam de suporte para auxiliá-las no entendimento dessa vivência, como é o caso de "O Tempo", que diz: "Ninguem pode evitar os meus damnos.../ Vou correndo sereno e constante:/ D'esse modo, de cem em cem annos,/ Fôrmo um seculo, e passo adiante." (BILAC, 1916, p. 64); já em "A Madrugada" comemora o nascer do dia; Em "Meio-dia", contempla-se a chegada desse período; e, por fim, "Meia-noite", todas as composições marcam os períodos/horários diários. Os poemas "A Infancia", "A Mocidade" e "A Velhice" ordenam os ciclos de existência pelos quais passa a vida humana.

As noções de temporalidades não nascem conosco, elas se formam. Considerando isso, a presença dos citados poemas foi tão importante para a formação da criança, pois o tempo é uma "[...] ordem que tem de ser aprendida, uma forma cultural que deve ser experimentada." (ESCOLANO, 2001, p. 44). Na nossa concepção, os poemas calendários supracitados ajudariam as crianças a regularem esse complicado sistema da conduta diária, pois, igualmente a um relógio, eles serviriam para organizar “[...] as primeiras percepções cognitivas da temporalidade e garantem a internalização dos valores da exatidão, da aplicação e da regularidade, que são, na expressão de Foucault, as virtudes fundamentais do tempo disciplinar." (ESCOLANO, 2001, p. 44). O modo como o livro indica a organização do tempo escolar, foi um contributo à "força" educativa que garantiu a sua estadia por mais de meio século nas salas de aulas.

Conforme aponta Faria Filho e Vago (2001), nos dias dos feriados de caráter cívico, a escola, além de oferecer e de participar, era o próprio espetáculo. Lajolo (1982) ressalta que a legislação educacional do período pretendia despertar a consciência nacional por meio de comemorações obrigatórias das datas cívicas - decretado pelo primeiro governo republicano 
-, pelo fortalecimento do ensino de língua, de história e de geografia do Brasil. Assim, pela construção dos poemas da seção em análise, percebemos o afinamento da escola com a propagação de datas comemorativas importantes para a construção de uma nova sociedade que se formava, e que os livros de leitura patrocinavam. Geralmente, como aponta Lajolo (1982), dentre os temas relativos às datas, destacam-se os de cunho rural, patriótico e religioso. A estudiosa detalha a temática de cada um deles:

[...] janeiro: festas, reabertura das aulas; fevereiro: carnaval; março: semana santa; abril: outono, Tiradentes; maio: libertação dos escravos; junho: festas juninas; julho: frio, comunhão familiar; agosto: chuva, leitura; setembro: primavera, Independência; outubro: descobrimento da América; novembro: finados, República; dezembro: férias (LAJOLO, 1982, p. 77, grifo nosso).

Pela síntese da seção que a autora elabora, percebemos que alguns poemas fazem referência às estações, o que dialoga com a seção anteriormente examinada, enquanto outras composições remetem às datas comemorativas visando à exaltação a episódios da história do Brasil. Tendo em vista essa situação, a obra também cumpriria a função de pretexto para o ensino de outras matérias e para reavivar, mantendo a memória, tais datas importantes para o povo republicano, assim, os escolares teriam uma instrução útil e divertida. O mesmo acontece com as composições poéticas e ilustrativas que remetem ao calendário escolar, como é o caso de "Janeiro", "Agosto" e "Dezembro", os quais nos debruçaremos a partir de agora.

Ao observar a gravura que ilustra o poema de abertura da seção "JANEIRO" (cf. Figura 2), referente mês da volta às aulas, ciclo novo que se inicia, nota-se as crianças (meninos) felizes com livros, indo em direção a um prédio que provavelmente seria a escola. 
Figura 2- Reprodução fotográfica da gravura que ilustra o poema "JANEIRO".

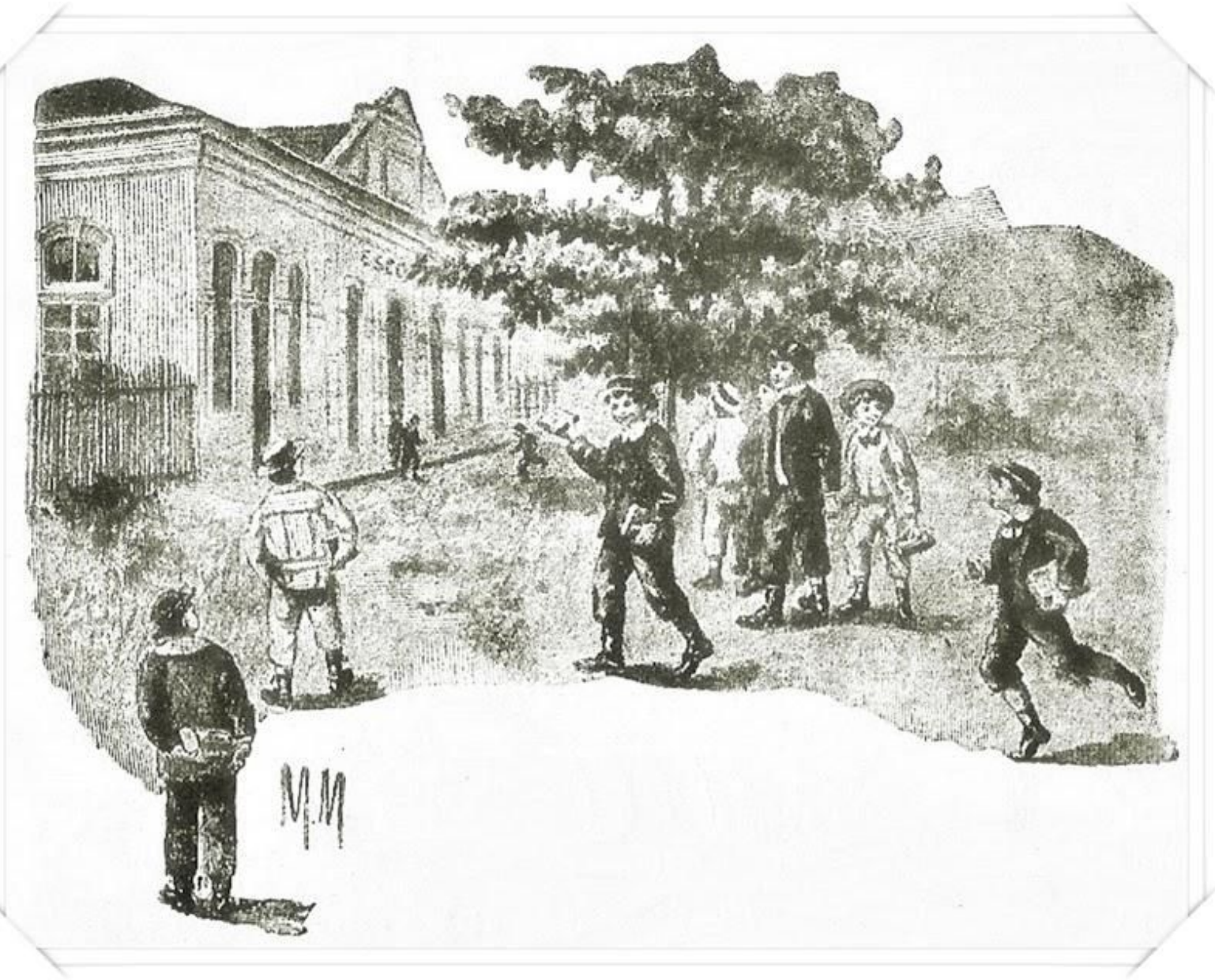

Fonte: Acervo particular.

A difusão de imagens de prédios escolares suntuosos também é uma das características dos livros infantis com tendências europeias. Conforme Escolano (2001, p. 25), "[...] os livros de leituras inseriam textos alusivos à escola como edifícios emblemáticos de povoados e cidades, bem situados, construídos segundo critérios de higiene e conforto [...]". No que diz respeito aos versos do poema, apenas o quinto e o sexto versos da terceira estrofe há referência ao retorno às aulas: "Eu sou o mez do estudo:/ As aulas vão se abrir!" (BILAC, 1916, p. 76). 
Em "AGOSTO" segue o mesmo direcionamento, o eu-poemático, por meio de um "nós democrático", como denomina Lajolo (1982, p. 129), solicita que "Deixemos em paz lá fora/ O balanço e o trampolim..." (BILAC, 1916, p. 89), para focar nas leituras: "Depois das lições, abramos/ Livros de contos; leiamos/ As ardentes narrações/ De aventuras, de viagens/ Por inhospitas paragens/ E por selvagens sertões..." (BILAC, 1916, p. 90).

Como se percebe, à medida que avança os meses do ano, os poemas vão controlando o tempo, as brincadeiras e as leituras das crianças, que com a chegada do último mês do ano, e mês das "- Ferias, collegios fechados/ E livros abandonados!..." (BILAC, 1916, p. 98) é o momento do descanso. É significativo mencionar que em "DEZEMBRO", a ilustração (cf. Figura 3) apresenta o mesmo cenário que constitui a do poema "JANEIRO", mas, ao invés das crianças estarem indo ao encontro da escola, elas estão saindo dela, possivelmente com seus parentes, o que de forma simbólica representa o fechamento do ciclo escolar anual. Desse diálogo entre as gravuras, podemos deduzir que, implicitamente, porque os versos não mencionam a questão do prédio escolar, trata-se de uma mesma escola, pois o cenário e o pano de fundo das imagens apresentam ângulos semelhantes. Ademais, as imagens do compêndio muitas vezes parecem agregar aos poemas novas perspectivas e significados que alargam o papel educativo da obra.

Figura 3- Ilustração que acompanha o poema "DEZEMBRO". 


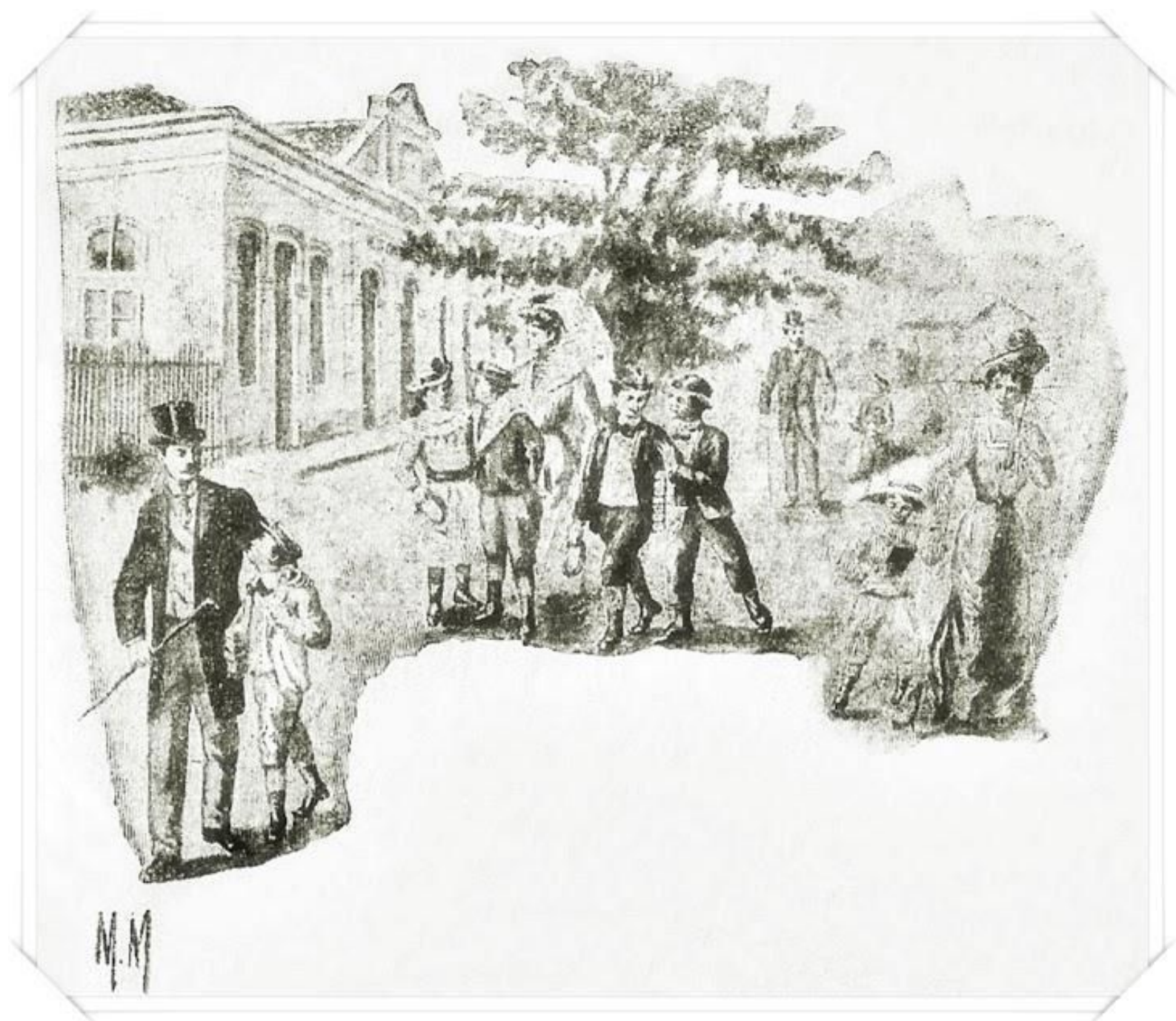

Fonte: Acervo particular.

Percebemos que, além dos meninos, há agora a presença de meninas e de seus parentes, que alegremente acompanham os escolares no retorno a casa, reforçando o afinamento entre a família e o espaço escolar. Muito possivelmente, a escola representada trata-se de um internato, fato que é reforçado pelos versos: “[...] Crenças! tendes saudade/ Da casa, da liberdade,/ Do carinho maternal?" (BILAC, 1916, p. 97) e pelo segundo verso do coro de encerramento do poema, "Vamos às casas regressar..." (BILAC, 1916, p. 98). Os versos explicitam o tempo que a criança ficou longe da sua família e que agora alegremente regressa ao seu lar e ao carinho doméstico. 
Em suma, o conjunto de poemas que enfatizamos ao longo deste trabalho representa uma memória coletiva vivenciada dentro e fora do ambiente escolar. Memória esta que perpassa vários campos, como o histórico, o educacional e o literário.

\section{CONSIDERAÇÕES FINAIS}

Com essas discussões, reforçamos a importância do estudo dessas obras de séculos passados, como manutenção da memória do patrimônio histórico e literário, bem como o reavivamento para a história da leitura literária na memória da educação brasileira.

Assim, atendemos o objetivo deste trabalho ao apresentar parte das múltiplas funções de Poesias infantis (1904), por meio da presença e da disposição das seções dos meses e das estações, as quais evidenciam uma necessidade escolar entressecular de contato com a natureza, organização temporal, interdisciplinaridade e o diálogo com outras formas de artes.

Destacamos que a própria construção didática das referidas seções revela o modo de organização escolar do período, que valorizava a cultura dos educandos - para quem se dirigia - e os interesses da nova camada dominante que surgia com a ascensão da Primeira República.

Em conclusão, deixamos a proposta de novos estudos - entendendo que estes impressos representativos do período de consolidações de sistemas constituem um patrimônio cultural por evocar uma memória infantil, escolar e literária do final do século XIX e início do XX - sobretudo, por principalmente ressaltar a relevância de estudar a obra poética infantil de Olavo Bilac, um cânone da literatura infantil e didática que atende a toda uma tradição literária emergente que formava aliança com a escola. 


\section{REFERÊNCIAS}

ALTMAN. R. Z. Brincando na história. In: DEL PRIORE, M. (Org.) História das crianças no Brasil. São Paulo: Contexto, 2013.

ALVES, J. H. P. Poesia e dança. In: PEREIRA, J. A.; SILVA, M. V. (org.). Literatura e outras linguagens. Coleção Crítica e Ensino. Campina Grande: Bagagem, 2016.

BILAC, O. Poesias infantis. Rio de Janeiro: Francisco Alves, 1904. Disponível em: <http://www.brasiliana.usp.br/handle/1918/00292400\#page/1/mode/1up> Acesso em: 02 abr. 2018.

Poesias infantis. Rio de Janeiro; São Paulo; Belo Horizonte: Francisco alves \& Cia; Paris: Aillaud; Lisboa: Alves \& Cia, 1916.

CHARTIER, R. A história cultural entre práticas e representações. Lisboa: DIFEL, 2002.

COELHO, N. N. Brasil-Século XIX. In: Dicionário crítico de literatura infantil e juvenil Brasileira: Séculos XIX e XX. 4. ed. ver. e ampl. São Paulo: Companhia Editora Nacional, 2006.

CORDEIRO, A. B. Dando vida a uma raiz: O ideário pedagógico da Primeira República na Poesia Infantil de Olavo Bilac. Dissertação - Universidade Federal do Paraná. Faculdade de Educação, 2005.2 Disponível em: <http://dspace.c3sl.ufpr.br:8080/dspace/bitstream/handle/1884/6028/andrea.pdf?sequenc e=1>. Acesso em: 18 abr. 2018.

ESCOLANO, A. Arquitetura como programa. Espaço-escola e currículo. In: FRAGO, A. V.; ESCOLANO, A. Currículo, espaço e subjetividade: a arquitetura como programa. Trad. Alfredo Veiga Neto. Rio de Janeiro: DP\&A, 2001.

FARIA FILHO, L. M.; VAGO, T. M. Entre relógios e tradições: elementos para uma história do processo de escolarização em Minas Gerais. In: VIDAL, D. G.; HILSDORF, M. L. S. (Org.). Brasil 500 Anos: Tópicas em história da educação. São Paulo: Edusp. 2001.

GOLDSTEIN, N. Versos, Sons e Ritmos. $5^{\text {a }}$ ed. São Paulo: Ática, 1989.

LAJOLO, M. P. Usos e abusos da literatura na escola: Bilac e a literatura escolar na República Velha. Rio de Janeiro: Globo, 1982.

Paulo: Ática, 1993.

No mundo da leitura. In: Do mundo da leitura para a leitura do mundo. São

LAJOLO, M. ZILBERMAN, R. Literatura infantil brasileira: história \& histórias - 6.ed - São Paulo: Ática, 2010. 
MARICONI, I. Como e por que ler poesia. In: Como e por que ler a poesia brasileira do século $X X$. Rio de Janeiro: Objetiva, 2002.

No mundo da leitura. In: Do mundo da leitura para a leitura do mundo. São Paulo: Ática, 1993.

VEIGA, C. G. Educação estética para o povo. In. LOPES, E. M. T. FARIA FILHO, L. M. VEIGA, C. G. (Org.) 500 anos de educação no Brasil. Belo Horizonte: Autêntica, 2011. (Coleção Historial)

ZILBERMAN, R. Como e por que ler a Literatura Infantil Brasileira. Rio de Janeiro: Objetiva, 2014.

Artigo recebido em: 30 de maio de 2018. Artigo aprovado em: 27 de setembro de 2018. 